JOURNAL ECONOMIC AND STRATEGY (JES)

Electronic ISSN : 2745-6544

Homepage :https://journal.utnd.ac.id/index.php/jes

\title{
PENGARUH KONFLIK KERJA DAN LINGKUNGAN KERJA TERHADAP SEMANGAT KERJA PEGAWAI KANTOR CAMAT MEDAN SUNGGAL
}

\author{
Dra. Rosniwaty Br Bangun ${ }^{1}$, Mareko Lombu ${ }^{2}$ \\ Universitas Tjut Nyak Dhien \\ Email Author: markuslombu55@gmail.com
}

\begin{abstract}
Abstrak
Setiap pegawai dalam organisasi akan berhadapan dengan konflik kerja dan lingkungan kerja yang berpengaruh terhadap Semangat Kerja Pegawai Kantor Camat medan Sunggal. Setelah dilakukan uji pada data yang diperoleh dari lapangan didapat hasilnya baik secara parsial maupun simultan variabel bebas berpengaruh positif dan signifikan terhadap variabel terikatnya yang ditunjukkan dengan nilai $\mathrm{F}$ dengan sig lebih kecil dari 0,05. Dengan begitu instansi perlu memperhatikan keduanya untuk meningkatkan semangat kerja pegawai.
\end{abstract}

Kata Kunci : Konflik Kerja, Lingkungan Kerja, Semangat Kerja

\begin{abstract}
Every employee in the organization will be faced with work conflicts and work environments that affect the work spirit of the Sunggal sub-district office employees. After testing the data obtained from the field, the results were obtained both partially and simultaneously the independent variables had a positive and significant effect on the dependent variable, which was indicated by the F value with a sig less than 0.05. Thus, agencies need to pay attention to both to increase employee morale.
\end{abstract}

Keywords : Work Conflicts, Working Environment, Employee Morale

\section{A. PENDAHULUAN}

Pelayanan instansi pemerintahan saat ini menjadi sesuatu yang sangat penting, masyarakat sekarang tidak segan untuk mengadu ke khalayak ramai jika ada sesuatu yang tidak sesuai dengan pelayanan dari suatu instansi pemerintahan sehingga pegawai dituntut untuk terus mampu memberikan pelayanan yang terbaik bagi seluruh masyarakat. Tidak dapat dipungkiri kalau pelayanan yang baik didukung oleh berbagai faktor yang seringkali dianggap sepele oleh sebagian orang. Artinya pelayanan yang baik tidak hanya didukung oleh seberapa tinggi pendidikan yang telah diterima seseorang tetapi lebih dari faktor tersebut. Pelayanan yang baik biasanya diberikan oleh mereka yang memiliki semangat, tentu saja semangat ini didukung oleh pola pikir dan

sikap dari si pegawai ada juga dukungan dari luar diri pegawai.

Karena begitu pentingnya pegawai pada instansi pemerintahan maka perlu untuk tetap menjaga semangat kerja. 
Hasibuan (2017:60) menyebutkan bahwa semangat kerja merupakan hasrat, kemauan seseorang yang sungguhsungguh untuk membereskan satu rangkaian kegiatan dengan cara yang teratur dan tepat waktu dalam menggapai prestasi yang diharapkan dan menunjukkan ketertarikan terhadap pekerjaan yang dilakukannya. Siapun pegawainya atau berada di instansi manapun perlu memberikan perhatian terhadap semangat kerja karena sebenarnya pada kondisi pegawai dalam keadaan kurang bersemangat maka sulit mencapai tujuan kerja yang maksimal.

Penyebab atau pendukung semangat kerja diantaranya konflik dilingkungan kerja. Nitisemito (2015:112) menyebutkan faktor-faktor tersebut diantaranya hubungan manusiawi berkaitan dengan konflik dan lingkungan kerja. Mangkunegara (2017:201) mengutarakan bahwa konflik kerja adalah "ketidaksesuaian harapan dan kenyataan akan tentang kejadian pada diri sendiri, orang lain serta organisasi yang dijalani seseorang. Biasanya pegawai tidak akan mampu bersemangat apabila dia memiliki konflik di tempat bekerjanya, pemikiran serta perasaan seseorang akan terganggu dengan konfilk yang dialaminya dan menimbulkan ketidaknyamanan dalam bekerja. Pemikiran lain yang diungkapkan oleh Robbins dan Judge (2015:132), konflik adalah "keadaan dimana seseorang telah melakukan sesuatu dan merugikan dirinya. Pikiran negatif akan memenuhi hari-harinya dan cenderung sensitif terhadap setiap tindakan dari orang atau oknum yang sedang memiliki konflik dengannya. Konflik juga ternyata tidak dapat dihindari berbagai organisasi sering menghadapinya dan pegawai di organisasi swasta cenderung memiliki kesempatan untuk mengakhiri konflik dengan meninggalkan tempat mereka bekerja dan memilih berkarir di tempat yang lain. Namun, penyelesaian konflik di instansi pemerintahan dengan cara mengundurkan diri atau pindah ke instansi lain pasti sangat sulit untuk dilakukan.Studi yang pernah dilakukan oleh Kurniawan, R. B. dkk (2018) mendapatkan hasil bahwa konfilk kerja memberi efek signifikan terhadap kinerja pegawai.

Ada banyak faktor yang menyebabkan konfik kerja diantaranya seperti yang terjadi di Kantor Camat Medan Sunggal konflik terjadi ketika tidak terjalin komunikasi yang baik antar pegawai. Dari tutur kata atau intonasi yang meninggi diidentikkan dengan ketidakcocokan antar pegawai. Konflik juga terjadi karena pegawai merasa ada ketidakadilan dalam pembagian kerja. Ada pegawai yang dirasa mendapatkan pekerjaan yang lebih ringan sedangkan yang lain mendapatkan pekerjaan yang lebih banyak. Mangkunegara (2017:202) menyebutkan penyebab konflik yaitu tidak ada koordinasi kerja, tidak ada deskripsi pekerjaan yang jelas, orientasi kerja yang berbeda-beda, perbedaan pemahaman mengenai maksud satuan kerja, perbedaan pandangan, sistem reward dan cara atasan dalam memberikan motivasi yang tidak sesuai.

Lingkungan kerja sebagai salah satu pendukung produktifitas kinerja pegawai. Karena berhubungan langsung dengan para pegawai, lingkungan kerja dikatakan baik apabali kinerja pegawai meningkat dengan optimal. Sebab pegawai merasa nyaman dan aman yang berdampak kinerja pegawai optimal dan menentukan keberhasilan tujuan organisasi/instansi. Sedarmayanti (2017:25), Sri Widodo (2015:95) menjelaskan lingkungan kerja sebagai wilayah sekitar yang selalu digunakan dan dinikmati atau dirasakan saat bekerja serta segala sesuatu yang dihadapi berupa peralatan dan fasilitas yang digunakan dalam bekerja.

Segala yang bersinggungan dengan pegawai dalam melaksanakan pekerjaannya sehari-hari dalam kondisi yang baik tentu saja memberikan semangat kerja yang baik pula demikian sebaliknya. Hal ini yang membuat organisasi berusaha 
menciptakan lingkungan fisik dan non fisik senyaman mungkin untuk menjaga semangat pegawainya.

Hasil prariset yang penulis temui dilapangan yang menjadi masalah lingkungan kerja di Kantor Camat Medan Sunggal adalah pegawai merasa kurang nyaman dengan kondisi yang ada karena sering terjadi cekcok dengan pegawai lain, tim kerja yang tidak aktif dan jarang bisa diajak bekerja sama dan peralatan kantor yang sering bermasalah karena kurangnya perawatan.

Hal yang diharapkan dari penelitian ini adalah untuk tahu efek konflik kerja dan lingkungan kerja terhadap semangat kerja pegawai kantor Camat Medan Sunggal secara parsial dan simultan.

\section{B. TINJAUN PUSTAKA}

Sri Widodo

(2015:104)

menerangkan semangat kerja adalah cerminan keadaaan sebenarnya dari pegawai dimana perusaan akan mendapat untung memiliki pegawai yang bersemangat karena absensi rendah, keluar masuk pegawai minim dan produktivitas tercapai.

Nitisemito (dalam Akbar 2018:20) mengatakan kalau semangat kerja pegawai adalah satu usaha yang dipakai instansi untuk menunjang kinerja, berikut faktorfaktor dalam mendeskripsikan semangat kerja: a. Absensi menyatakan ketidakhadiran pegawai dalam menjalankan tugasnya yang disebabkan kondisi yang tidak dapat dihindari, $b$. Kerja sama menunjukkan sifat terbuka dari pegawai untuk melakukan pekerjaan dengan bersama-sama untuk mencapai tujuan yang ingin dicapai, c. Lingkungan kerja yang menunjukkan segala sesuatu yang berhubungan dengan pegawai saat melakukan tugasnya, d. Kedisiplinan sebagai pola sikap dan perilaku pegawai terhadap setiap aturan yang ada dalam organisasi.

Mangkunegara (2017:201), menjelaskan konflik kerja adalah "ketidaksesuaian dalam diri pegawai akan harapan dan kenyataan akan sikap dan perbuatan orang lain maupun pengelolaan yang dilakukan pada tempatnya bekerja.

Fitriana dalan Noor Annisa(2015:12) menyebutkan beberapa indikator konflik kerja sebagai berikut : a) Kesalahan komunikasi artinya perbedaan memahami pesan yang diterima dari pesan yang disampaikan menyebabkan tujuan pesan tidak sesuai dengan yang dibutuhkan. b) Perbedaan tujuan, hal ini sering terjadi ketika yang melakukan komunikasi memiliki perbedaan tujuan yang ingin dicapai. c) perbedaan persepsi antara pegawai, d) pekerjaan yang harus diselesaikan dalam tim, e) bagaimana rekan kerja memperlakukan sesamanya yang sering disebut dengan kesalahan afeksi.

Afandi (2018:66) mengartikan lingkungan adalah semua yang berinteraksi dengan dirinya selama melakukan aktivitas namun tidak dapat dilihat akan tetapi bisa dirasakan seperti suhu udara, sirkulasi udara, kecerahan ruangan, keributan atau ketenangan, pengelolaan sampah dan kebersihan ruang kerja dan kecukupan perlengkapan kerja. Lingkungan kerja juga termasuk bagaimana seseorang bergaul dengan rekan kerjanya. Jika lingkungan kerja pegawai dalam kondisi baik seperti lokasi kerja yang bersih, tenang atau tidak bising, pencahayaan yang baik, tata ruang yang baik, peralatan kerja yang baik akan memberikan kenyamanan bagi pegawai untuk bekerja dengan baik.

Indikator lingkungan kerja fisik dan non fisik yang dipakai dalam penelitian ini adalah dari pendapat yang dikemukakan oleh Nitisemito (2015:103):

a) Fasilitas. Terdapat fasilitas yang memadai sehingga mampu mendukung sarana dan prasarana dari kinerja pegawai.

b) Pencahayaan. Diupayakan dalam sebuah lingkungan kerja memiliki cukup ruang pencahayaan. 
c) Suhu udara. Tujuan dengan suhu udara adalah agar mampu mengotrol situasi suasana dalam bekerja.

d) Tata ruang. Tata ruang adalah salah satu hal yang mendasar dalam mengupayakan adanya sebuah struktur ruangan yang memadai dalam bekerja.

e) Hubungan harmonis. Adanya sebuah korelasi hubungan antara satu pegawai dengan pegawai lainnya atau atasan dengan bawahan guna mencapai tujuan kinerja bersama.

\section{METODE PENELITIAN}

Populasi yang merupakan objek penelitian (Kuncoro, 2003: 103) ini adalah semua pegawai kantor Camat Medan Sunggal baik yang berstatus PNS dan pegawai Honorer yang berjumlah 77 orang. Sampel yang merupakan bagian yang ideal atau mampu menyatakan populasi studi (Kuncoro, 2003: 107) ini seluruh populasi dijadikan sampel apabila populasi dibawah 100 orang (Rusiadi 2014:30).

Variabel atau hal yang boleh melainkan atau menukar nilai, nilai yang tidak sama pada waktu yang tidak sama pada objek yang sama dan nilai bisa saja tidak sama pada waktu yang sama bagi orang yang beda (Kuncoro 2003: 41). Sesuai dengan judulnya variabel studi ini yang pertama yang kedua Lingkungan kerja $\left(\mathrm{X}_{2}\right)$ untuk variabel bebas dan Semangat kerja (Y) untuk variabel terikat.

Teknik pengumpulan data yang dipakai untuk memperoleh seluruh data yang dibutuhkan yaitu studi dokumentasi dan kuesioner (angket) dimana kuesioner menggunakan skala likert yakni skala dengan 5 tingkat referensi jawaban Sangat Setuju (SS) dengan nilai 5, Setuju (S) dengan nilai 4, Kurang Setuju (KS) dengan nilai 3, Tidak Setuju (TS) dengan nilai 2, dan Sangat Tidak Setuju (STS) dengan nilai 1. Data dianalisis dengan metode regresi linier berganda.

\section{HASIL PENELITIAN}

\section{Uji Kualitas Data}

a. Uji Validitas

Hasil uji validitas diperoleh untuk semua variabel berada di atas $\mathrm{r}$ tabel (> 0,2242) oleh karena itu instrumen yang dipakai dalam penelitian ini valid dan dapat dilanjutkan ke uji selanjutnya.

\section{b. Uji Reliabilitas}

Hasil uji reliabilitas dimana ketentuannya instrument dinyatakan valid jika Cronbach's alpha bernilai > 0,6 memenuhi yang bermakna intrumen yang dipakai adalah reliabel atau kuesioner yang dipakai akan menunjukkan hasil sama apabila dipakai berulang-ulang pada waktu yang beda.

\section{Uji Asumsi Klasik}

Sangat penting melakukan uji asumsi klasik yakni untuk memastikan apakah persamaan regresi mempunyai estimasi atau perkiraan yang tepat, tidak bias, dan konsisten.

\section{a. Uji Normalitas}

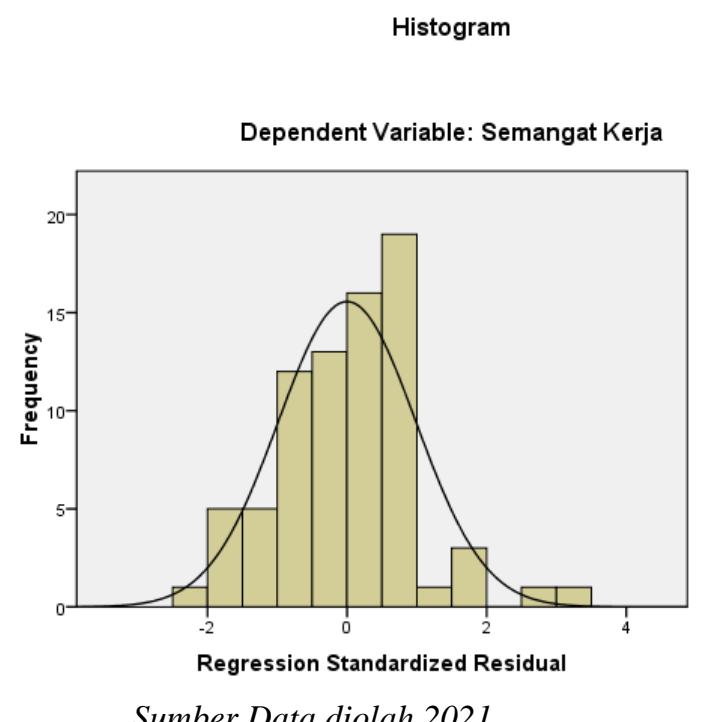

Gambar 1. Histogram Normalitas

Metode yang dapat digunakan untuk normalitas antara lain, analisis grafik dan analisis statistik. Uji normalitas dalam penelitian dilakukan dengan cara analisis 
grafik. Normalitas dapat dideteksi dengan melihat penyebaran data (titik) pada sumbu diagonal dari grafik atau dengan melihat histogram dari residualnya.

Normal P-P Plot of Regression Standardized Residu

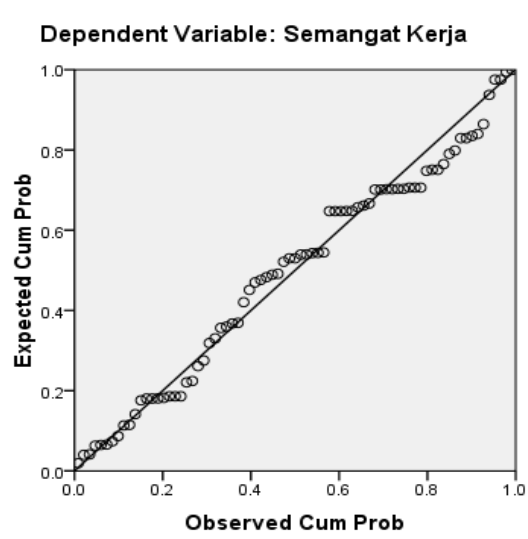

Sumber Data diolah 2021

\section{Gambar 2. Normalitas P plot}

Gambar di atas mengindikasikan bahwa model regresi telah memenuhi asumsi yang telah dikemukakan sebelumnya, sehingga data dalam model regressi penelitian ini cenderung normal dikarena bedasarkan gambar diatas distribusinya mengikuti garis diagonal.

\section{b. Uji Multikoliniaritas}

Uji ini digunakan untuk menguji apakah pada model regressi ditemukan kolerasi yang kuat antar variable independen ketentuan pengujiannya bisa dilihat dari tabel dibawah ini.

\section{Tabel 1. Hasil Uji Multikolinieritas.}

\begin{tabular}{|l|r|r|r|r|}
\hline \multicolumn{1}{|c|}{ Coefficients $^{\mathbf{a}}$} & $\begin{array}{c}\text { Unstandardized } \\
\text { Coefficients }\end{array}$ & \multicolumn{2}{|c|}{$\begin{array}{c}\text { Collinearity } \\
\text { Statistics }\end{array}$} \\
\cline { 2 - 5 } Model & $\mathrm{B}$ & $\begin{array}{c}\text { Std. } \\
\text { Error }\end{array}$ & Tolerance & VIF \\
\hline 1 (Constant) & 13.434 & 3.184 & & \\
$\begin{array}{l}\text { konflik } \\
\text { kerja }\end{array}$ & .388 & .105 & .694 & 1.441 \\
$\begin{array}{l}\text { Lingkungan } \\
\text { kerja }\end{array}$ & .218 & .087 & .694 & 1.441 \\
\hline
\end{tabular}

\section{Coefficients $^{\mathrm{a}}$}

\begin{tabular}{|l|r|r|r|r|}
\hline & \multicolumn{2}{|c|}{$\begin{array}{c}\text { Unstandardized } \\
\text { Coefficients }\end{array}$} & \multicolumn{2}{|c|}{$\begin{array}{c}\text { Collinearity } \\
\text { Statistics }\end{array}$} \\
\cline { 2 - 5 } & $\mathrm{B}$ & \multicolumn{1}{c|}{$\begin{array}{c}\text { Std. } \\
\text { Error }\end{array}$} & Tolerance & VIF \\
\hline 1 Model $($ Constant) & 13.434 & 3.184 & & \\
$\begin{array}{l}\text { konflik } \\
\text { kerja }\end{array}$ & .388 & .105 & .694 & 1.441 \\
$\begin{array}{l}\text { Lingkungan } \\
\text { kerja }\end{array}$ & .218 & .087 & .694 & 1.441 \\
\hline
\end{tabular}

a.

Dependent

Variable: semangat

kerja

Sumber Data diolah 2021

Tabel di atas menunjukkan kalau kedua variable independent memiliki nilai VIF dalam batas toleransi yang telah di tentukan sehingga tidak terjadi multikolinearitas dalam variable independent penilaian ini karena cara yang digunakan untuk menilainya adalah dengan melihat nilai Tolerance $>0,10$ maka tidak terdapat multikolinearitas, demikian halnya dengan nilai VIF untuk variable konflik kerja dan lingkungan kerja adalah $1.411>0,10$ maka data dalam penelitian ini tidak terjadi multikolinearitas.

\section{c. Uji Heterodekasitas}

Scatterplot

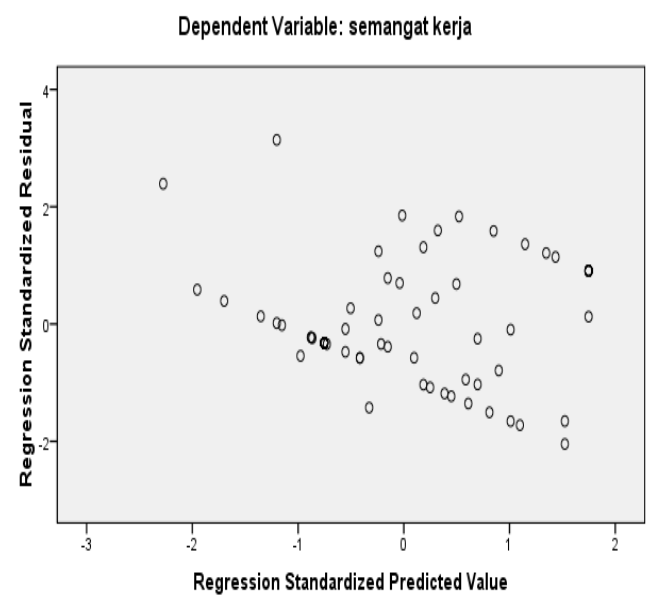

Sumber Data diolah 2021

Gambar 3. Scatterplot 
Gambar di atas telah menggambarkan titik-titik menyebar secara acak, tidak membentuk pola yang jelas teratur, serta tersebar baik diatas maupun di bawah angka 0 pada sumbu Y. dengan demikian "tidak terjadi heterokedastisitas " pada tabel regresi.

\section{Uji Regresi Linier Berganda}

Hasil Uji disajikan berikut ini:

Tabel 2. Hasil Uji

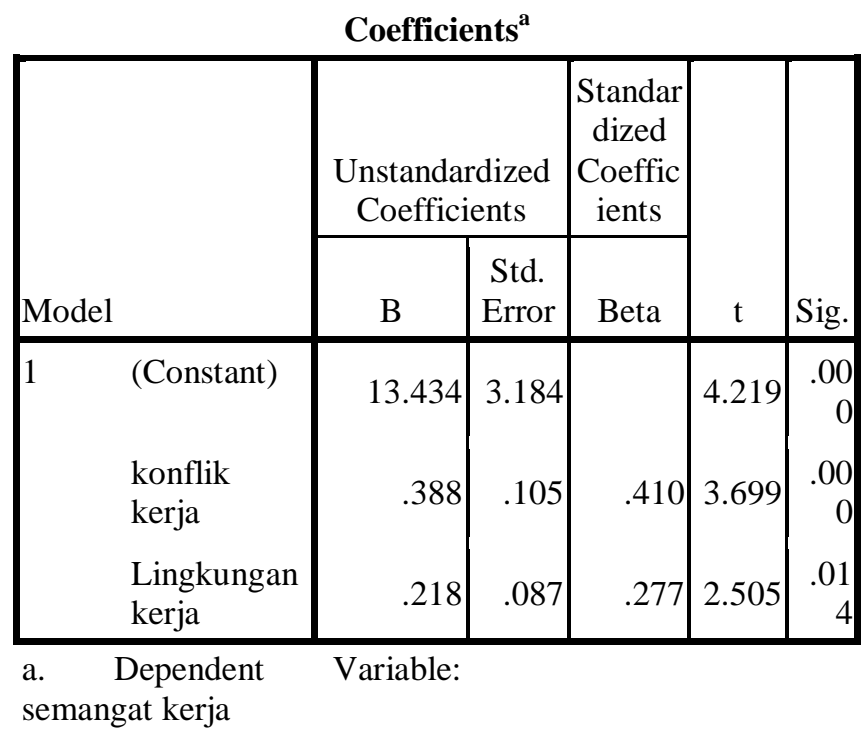

Sumber: Data diolah 2021

Dari olahan data tabel di atas dibentuk dalam bentuk persamaan yaitu :

$$
\mathrm{Y}=13.434+0.388+0,218+\mathrm{e}
$$

Persamaan tersebut dimaknai sebagai berikut:

a. Nilai konstanta sebesar $=13.434$ menggambarkan apabila Konflik kerja dan lingkungan kerja pada keadaan konstan tidak mengalami perubahan (ceteris paribus) maka Semangat kerja Pegawai Kantor Camat Medan Sunggal senilai $13.434 \%$.

b. Koefisien regresi $X_{1}$ adalah sebesar 0,388 menggambarkan konflik kerja akan memberi dampak positif terhadap semangat kerja sebesar 0,388 persen dengan catatan kondisi lingkungan kerja dalam keadaan konstan atau tidak mengalami perubahan (ceteris paribus). c. Koefisien regresi $\mathrm{X}_{2}$ adalah sebesar 0,218 menggambarkan lingkungan kerja memberi efek positif bagi semangat kerja sebanyak 0,218 persen dengan catatan bahwa konflik kerja dalam keadaan konstan atau tidak mengalami perubahan maka akan.

\section{Uji Hipotesis}

Berikut disajikan hasil pengolahan data dengan analisis regresi linier berganda untuk mendapatkan efek antar variabel:

\section{a. Uji t (Uji Secara Parsial)}

Uji parsial studi ini untuk pengaruh Konflik kerja terhadap Semangat kerja pada Pegawai Kantor Camat Medan Sunggal adalah signifikan yang ditunjukkan dari nilai sig 0, 000. Maka hipotesa Ho ditolak dan $\mathrm{Ha}$ diterima. Untuk variabel lingkungan kerja secara parsial juga berpengaruh signifikan terhadap semangat kerja pegawai kantor Camat Medan Sunggal dengan nilai sig yang didapat sebesar 0,014.

\section{b. Uji F (Uji Simultan)}

Hasil Uji F studi ini ditampilkan dalam tabel.

Tabel 3. Hasil Uji F

ANOVA $^{b}$

\begin{tabular}{|l|c|c|c|c|c|}
\hline Model & $\begin{array}{c}\text { Sum of } \\
\text { Squares }\end{array}$ & df & $\begin{array}{c}\text { Mean } \\
\text { Squar } \\
\mathrm{e}\end{array}$ & $\mathrm{f}$ & Sig. \\
\hline 1 Regression & 285.876 & 2 & $\begin{array}{c}142.9 \\
38\end{array}$ & 21.771 & $.000^{\mathrm{a}}$ \\
Residual & 485.838 & 74 & 6.565 & & \\
Total & 771.714 & 76 & & & \\
\hline
\end{tabular}

a. Predictors: (Constant), lingkungan kerja, konflik kerja

b. Dependent Variable: semangat kerja

Sumber Data diolah 2021

Tabel 3 untuk uji F sebesar 0,000 lebih kecil dari 0,05 hal ini berarti secara simultan Konflik kerja dan lingkungan kerja berpengaruh signifikan terhadap Semangat kerja pada Pegawai Kantor Camat Medan Sunggal. 


\section{Koefisien Determinasi}

Tabel 4. Hasil Koefisien Determinasi

Model Summary

\begin{tabular}{|c|c|c|c|c|}
\hline Model & $\mathrm{R}$ & $\begin{array}{c}\mathrm{R} \\
\text { Square }\end{array}$ & $\begin{array}{c}\text { Adjusted R } \\
\text { Square } \\
\end{array}$ & $\begin{array}{l}\text { Std. Error of the } \\
\text { Estimate }\end{array}$ \\
\hline 1 & $\begin{array}{r}609 \\
\text { a }\end{array}$ & .370 & .353 & 2.56230 \\
\hline
\end{tabular}

a. Predictors: (Constant), lingkungan kerja, konflik kerja

Sumber Data diolah 2021

Berdasarkan pengolahan data didapat $R$ Square sebesar 0,370 , angka ini mengandung makna bahwa semangat kerja mampu diterangkan oleh konflik kerja dan lingkungan kerja sebesar 37 persen, dan 63 persen sisanya diterangkan oleh faktor lain diluar penelitian.

\section{PEMBAHASAN.}

Ditemukan hasil studi konflik kerja berpengaruh signifikan terhadap semangat kerja pegawai kantor Camat Medan Sunggal. Hasil ini mengandung makna ketika setiap pegawai bekerja sesuai dengan tukas dan fungsinya masingmasing maka tidak akan mengganggu pegawai lainnya, artinya setiap pegawai bekerja dengan teratur dan tidak ada benturan kepentimgan diantara para pegawai. Jelasnya pembagian kerja siapa dan apa yang dikerjakan membantu mengurangi konflik dalam setiap instansi. Studi sebelumnya memberi hasil yang sama seperti penelitian ini diungkapkan oleh Achmad L. Dan Andriani D. (2020) semakin rendah konflik yang terjadai dalam sebuah organisasi maka akan menciptakan semangat kerja yang baik bagi para pegawainya.

Konflik terjadi tidak serta merta karena adanya perbedaan pendapat, tetapi cenderung dikarenakan perasaan tidak adil yang dirasakan pegawai dibandingkan dengan perlakuan atau tanggung jawab rekan sekerjanya. Pendapat ini diungkapkan dalam penelitian yang dilakukan oleh Donkor P, Afriye S dkk. (2015).

Untuk lingkungan kerja juga menunjukkan adanya pengaruh yang signifikan terhadap semangat kerja. Kondisi lingkungan yang baik akan membuat pegawai mengalami perasaan yang baik sehingga mereka mampu memberikan hasil yang terbaik dalam bekerja. Pekerja akan menikmati pekerjaannya Muskita C. and Kazimoto P. (2017).

\section{KESIMPULAN}

1. Konflik kerja berpengaruh positif dan signifikan terhadap semangat kerja yang ditunjukan dari nilai sig lebih kecil dari 0,05 .

2. Lingkungan kerja berpengaruh dan signifikan terhadap Semangat kerja yang ditunjukan dari nilai sig lebih kecil dari 0,05.

3. Konflik kerja dan lingkungan kerja berpengaruh terhadap Semangat kerja pada Pegawai Kantor Kecamatan Medan Sunggal, yaitu nilai sig $(0,000<$ $0,05)$.

\section{DAFTAR PUSTAKA}

A.A. Anwar Prabu Mangkunegara. (2017). Manajemen Sumber Daya Manusia Perusahaan, Bandung : Remaja Rosdakarya.

Achmad L. Dan Andriani D (2020). Dampak Stres dan Konflik terhadap Aemangat kerja Karyawan pada Perusahaan Meubel di Sidoarjo, Indonesia. Indonesian Journal of Law and Economics Review .Volume 6. Pp 1-12.

Afandi, P. (2018). Manajemen Sumber Daya Manusia (Teori, Konsep dan Indikator). Riau: Zanafa Publishing. 
Akbar, Andi Syahputra.2018. Pengaruh Stres Kerja Dan Konflik Kerja Terhadap Semangat Kerja Karyawan Pada PT. Perkebunan Nusantara Iv (Persero) Unit Usaha Adolina Perbaungan Serdang Bedagai, Skripsi.Fakultas Ekonomi Dan Bisnis Universitas Medan Area.

Badriyah, Mila, 2015. Manajemen Sumber Daya Manusia, Pustaka Setia, Bandung.

Donkor P, Afriye S dkk. (2015). Effect of Conflict on Employees performance: Evidence Coca Cola Company Limited, Kumasi Branch. American Scientific Research Journal for Enginering, Technology, and Sciences (ASRJETS). Volume 14, No. 3, pp 44-53.

Ghozali, Imam. 2016. Aplikasi Analisis Multivariete Dengan Program IBM SPSS 23 (Edisi 8). Cetakan ke VIII. Semarang : Badan Penerbit Universitas Diponegoro.

Hasibuan, Malayu S.P.. 2017. Manajemen Sumber Daya Manusia. Edisi Revisi. Jakarta: Bumi Aksara.

Kurniawan, R. B. dkk (2018). The Effect Of Work Conflict And Job Stress On Employees Performance With Organizational Commitment As Intervening Variable, 2018. Jurnal Management dan kewirausahaan. Vol. 6, No. 1, 2018: 1-8.

Lydia Amalia Pradita.2018. Pengaruh Beban Kerja Dan Konflik Kerja Terhadap Semangat Kerja Karyawan Pada PT. Telekomunikasi Indonesia, Tbk Kantor Divisi Regional 1 Sumatera. SkripsiFakultas Ekonomi Dan Bisnis Universitas Muhammadiyah Sumatera Utara Medan.
Muskita C and Kazimoto P (2017). Workplace Environment and Employee Morale: A Study of Selected Organizations in Jakarta, Indonesia. Human Behavior, Development and Society. Volume 16 pp. 108 - 117.

Nitisemito, Alex., (2015), Manajemen Sumber Daya Manusia, Pustaka setia, Bandung.

Rivai, Veithzal dan Ella, Sagala 2015. Manajemen Sumber Daya Manusia untuk Perusahaan, Rajawali Pers, Jakarta. Robbins, Stephen P. dan Judge, 2008. Perilaku Organisasi, Edisi dua belas, Salemba Empat, Jakarta.

Robbin \& Judge. 2015. Perilaku Organisasi Edisi 16. Jakarta. Salemba Empat.

Sedarmayanti, 2017. Manajemen sumber daya manusia reformasi birokrasi dan manajemen pegawai negeri sipil. Rafika Aditama : Bandung

Sri Widodo Soedarso. 2015. Manajemen Sumberdaya Manusia : teori, prencanaan sttrategi, isu-isu utama dan globalisasi. Bandung : Manggu Media.

Sofyan, Edy dan Julkarnain. 2019. Pengaruh Pengalaman Kerja Dan Semangat Kerja Terhadap Kinerja Karyawan Di PT. Dutagriya Sarana Medan, Jurnal Riset Manajemen \& $\begin{array}{llll}\text { Bisnis } & \text { (JRMB), } & \text { Vol.4 } & \text { No.2 }\end{array}$ Nopember 2019.

Sugiyono. 2017. Metode Penelitian Pendidikan Pendekatan Kuantitatif, Kualitatif, dan $R \& D$. Bandung: Alfabeta

Widodo, Sri. 2017. Msnajemen sumber daya manusia. Teori perencanaan 
strategi, isus-isu utama dan

globalisasi. Mangru media :

Bandung.

Journal Economic And Strategy (JES) |Volume 2|No 2|Juli-Desember|2021|pp.1 - 9 